\title{
Korelasi resistive index ginjal dengan proteinuria pada pasien diabetes melitus tipe 2
}

\author{
Achi Rasma Welaty ${ }^{1}$, Nurlaily Idris ${ }^{1}$, Bachtiar Murtala ${ }^{1}$, Andi Alfian Zainuddin ${ }^{2}$, Hasyim \\ Kasim $^{3}$, Nikmatia Latief ${ }^{1}$ \\ 1. Departemen Radiologi, Fakultas Kedokteran, Universitas Hasanuddin; 2. Departemen IKM \& IKK, \\ Fakultas Kedokteran, Universitas Hasanuddin; 3. Departemen IImu Penyakit Dalam, Fakultas \\ Kedokteran, Universitas Hasanuddin
}

Korespondensi: Achi Rasma Welaty; e-mail: achirasmawelaty.dr@gmail.com

\begin{abstract}
Abstrak
Tujuan: Penelitian ini bertujuan mengetahui korelasi resistive index ginjal dengan proteinuria pada pasien diabetes melitus tipe 2. Metode: Penelitian ini dilakukan di Bagian Radiologi RS Pendidikan Universitas Hasanuddin Makassar pada Maret s/d Juni 2019. Penelitian ini adalah penelitian deskriptif dengan kajian potong lintang. Pertama dilakukan penilaian proteinuria, perhitungan eGFR, dan melakukan ultrasonografi Doppler sehingga mendapatkan nilai resistive index. Analisis data statistik melalui uji korelasi Spearman. Sampel penelitian ini sebanyak 82 sampel dengan 41 sampel disertai proteinuria dan dengan 41 sampel tanpa disertai proteinuria. Hasil: Penelitian menunjukkan korelasi kuat antara resistive index ginjal dengan proteinuria $(r=0,449$ dan $r=0,551)$ dan memiliki hubungan yang signifikan $(p<0,0001)$. Untuk korelasi resistive index ginjal dengan eGFR terdapat korelasi yang kuat $(r=0,604$ dan $r=0,666)$ serta hubungan yang signifikan $(p<0,0001)$. Dan terdapat korelasi yang cukup antara proteinuria dengan eGFR serta memiliki hubungan yang signifikan $(r=0,449 ; p<0,0001)$. Simpulan: Semakin tinggi kadar proteinuria, maka semakin tinggi nilai resistive index ginjal pada pasien diabetes melitus tipe 2 . Terdapat hubungan yang cukup kuat antara resistive index ginjal kanan dan kiri dengan eGFR pada pasien diabetes melitus tipe 2. Dimana semakin tinggi nilai resistive index ginjal, maka semakin rendah nilai eGFR (semakin tinggi stadium PGK).
\end{abstract}

Kata kunci: ultrasonografi; resistive index ginjal; proteinuria; diabetes melitus tipe 2

\section{Abstract}

Objective: This study discusses the resistive index of kidney with proteinuria in patients with type 2 diabetes mellitus. Method: This study was conducted in the Radiology Department of Hasanuddin University Education Hospital from March to June 2019, using a descriptive study with cross-sectional method. The first was assessment of proteinuria, calculated eGFR, and performed Doppler ultrasound obtaining a resistive index value. Data were analyzed using Spearman assessment test. The sample of this study were of total 82 samples, 41 samples with proteinuria and 41 samples without proteinuria. Results: The study showed a strong correlation between renal resistive index and proteinuria $(r=0.449$ and $r=0.551$ ) and had a significant relationship ( $p<0.0001)$. Renal resistive index with eGFR also showed a strong correlation ( $r=0.604$ and $r=0.666)$ with a significant relationship $(p<0.0001)$. Proteinuria with eGFR showed sufficient correlation with a significant relationship ( $r=0.449 ; p<0.0001)$. Conclusion: Levels of proteinuria increases with increasing value of the renal resistive index in patients with type 2 diabetes mellitus. There can be a strong relationship between the resistive index of the right and left kidney with eGFR in patients with type 2 diabetes mellitus. In other hand, the higher the value of the renal resistive index, the lower the eGFR value (higher stage of chronic renal disease).

Keywords: ultrasonography; resistive index renal; proteinuria; type 2 diabetic mellitus 


\section{PENDAHULUAN}

Salah satu penyebab gagal ginjal kronik adalah diabetes melitus tipe $2 .{ }^{1}$ Diabetes melitus tipe 2 disertai microalbuminuria akan didiagnosis sebagai nefropati diabetik yang akan terjadi 20 tahun setelah didiagnosis, kemudian sekitar 20\% akhirnya mengalami stadium akhir. ${ }^{2,3}$ Pada pasien diabetes dengan fungsi ginjal normal, $65 \%$ dari mereka yang terkena tipe 1 dan 25\% dari mereka yang terkena tipe 2 memiliki nilai $\mathrm{RI} \geq 0,70 .{ }^{4}$ Pemeriksaan USG Doppler dengan color atau power Doppler, merupakan metode yang mudah diterapkan, non-invasif dan memiliki kemampuan tidak hanya untuk mengetahui karakteristik morfologi ginjal tapi dapat mendiagnosis stenosis arteri renalis, mengukur resistensi pembuluh darah parenkim ginjal. ${ }^{5}$ Peningkatan resistive index menggambarkan adanya proses fibrosis renal, yang mengakibatkan pengurangan luas pembuluh darah intrarenal dan akibatnya terjadi peningkatan resistensi pembuluh darah intrarenal, sehingga resistive index ginjal dapat menjadi prediktor independen dari penurunan fungsi ginjal. ${ }^{6}$ Dan dapat memberikan informasi diagnostik dan prognosis sebelum terjadi gagal ginjal stadium akhir. ${ }^{7}$

\section{METODE}

Penelitian ini merupakan penelitian deskriptif yang bertujuan untuk mengetahui korelasi resistive index ginjal dengan proteinuria pada pasien diabetes melitus tipe 2 di Rumah Sakit Pendidikan Universitas Hasanuddin Makassar, yang dilakukan dari bulan Maret sampai Juni 2019. Populasi penelitian adalah semua pasien diabetes melitus tipe 2 yang memiliki hasil pemeriksaan proteinuria yang dikirim dari bagian rawat jalan dan rawat inap penyakit dalam yang dirujuk ke bagian radiologi Rumah Sakit Pendidikan. Besar sampel penelitian ini adalah 82 sampel (41 sampel dengan proteinuria dan 41 sampel tanpa proteinuria). Pengambilan sampel dilakukan dengan cara consecutive sampling yaitu semua pasien yang memenuhi kriteria dimasukkan dalam penelitian sampai besar sampel yang dibutuhkan terpenuhi.

Sampel pada penelitian ini adalah yang memenuhi kriteria inklusi sebagai berikut: (1) semua pasien diabetes melitus tipe 2; (2) semua pasien diabetes melitus tipe 2 yang disertai hasil pemeriksaan proteinuria; (3) jenis kelamin laki-laki dan perempuan; (4) umur 18-70 tahun; (5) tekanan darah normal atau hipertensi; (6) bersedia ikut dalam penelitian dengan mengisi dan menandatangani informed consent. Dan kriteria eksklusi yaitu: (1) semua pasien diabetes melitus tipe 2 dengan nephrolith; (2) semua pasien diabetes melitus tipe 2 dengan kelainan polikistik; semua pasien diabetes melitus tipe 2 dengan hydronephrosis; (3) semua pasien diabetes melitus tipe 2 dengan kelainan ginjal polikistik; (4) semua pasien diabetes melitus tipe 2 dengan kelainan kongenital. 
Definisi operasional dan kriteria objektif penelitian sebagai berikut: (1) resistive index adalah pengukuran arteri ginjal dengan menggunakan Doppler Ultrasound untuk menilai resistensi arteri renalis. ${ }^{8} \mathrm{RI}$ lebih dari 0,70 merupakan batas maksimal nilai normal. ${ }^{9}$ Pengambilan sampel untuk RI dilakukan pada level arcuata/interlobar renalis yang berdekatan dengan medulla pyramids pada pool superior, median dan inferior; ; 2 ) adanya albumin dalam urin manusia yang melebihi nilai normal yaitu $>20 \mu \mathrm{g}$ disebut mikroalbuminuria dan $>300$ $\mu \mathrm{g}$ disebut makroalbuminuria atau proteinuria ${ }^{10}$; (3) eGFR MDR adalah formula untuk memperkirakan kecepatan penyaringan atau filtrasi glomerulus yang dinilai menggunakan rumus Cockroft-Gault serta tersedia dengan aplikasi kalkulator eGFR dan kemudian memasukkan nilai BB, umur, jenis kelamin dan kreatinin pasien. ${ }^{11}$
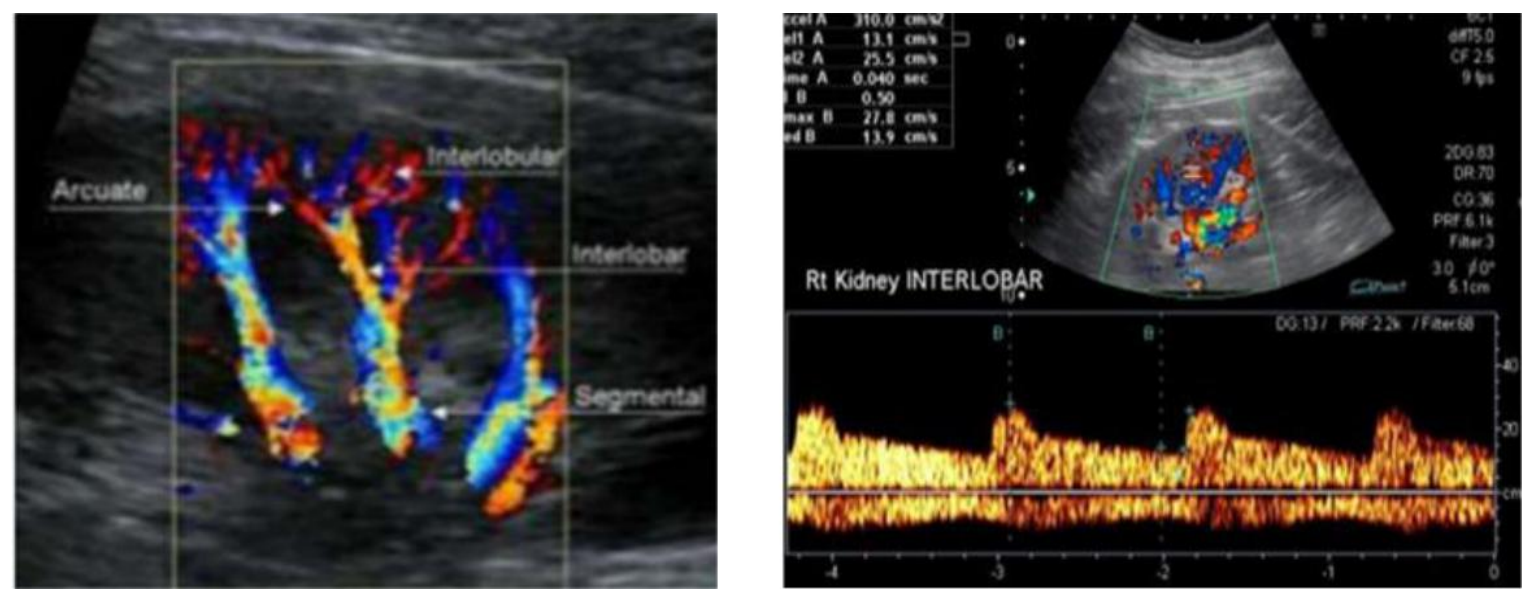

Gambar 1. Pengukuran Resistive Index. Sampel volume diletakkan pada arteri intrarenal (arcuata atau interlobar) dengan panduan Color Doppler. Kaliper kemudian diletakkan pada puncak systole dan End Diastole kemudian dihitung dengan formula (PSV-EDV)/PSV.

Pemeriksaan dilakukan dengan terlebih dahulu identifikasi dan peng-input-an data pasien yang memenuhi kriteria inklusi, serta penjelasan mengenai pemeriksaan yang akan dilakukan, jika pasien setuju kemudian dilakukan pengisian dan penandatanganan informed consent oleh pasien. Kemudian menentukan nilai eGFR melalui aplikasi kalkulator eGFR, selanjutnya pasien menjalani pemeriksaan USG ginjal dengan menggunakan transduser konveks frekuensi 3,5-5 $\mathrm{MHz}$. Posisi supine atau lateral decubitus jika kontur ginjal terhalang udara di saluran cerna, kemudian dilakukan scan longitudinal mengikuti akses ginjal. Dilakukan pemeriksaan ginjal jika sesuai kriteria inklusi. Kemudian dilakukan pengukuran resistive index (RI) pada arteri arcuata/interlobaris kedua ginjal yang berdekatan dengan medulla renalis, pengukuran dilakukan pada beberapa bagian berbeda (superior, median dan lower). Cara pengambilan resistive index renalis dapat terlihat pada Gambar $1^{7}$, Hasil penelitian dicatat dalam lembaran format penelitian kemudian dilakukan analisis data dan hasilnya disajikan dalam bentuk tabel. 


\section{HASIL DAN PEMBAHASAN}

Penelitian dilakukan pada 82 subjek (41 subjek dengan proteinuria dan 41 subjek tanpa proteinuria) dengan pemeriksaan Resistive index Doppler ultrasound dan perhitungan eGFR. Berdasarkan Tabel 1 menunjukkan distribusi sampel pasien diabetes melitus tipe 2 pada penelitian ini adalah 82 orang, lebih banyak pada perempuan $(58,5 \%)$, sisanya adalah lakilaki (41,5\%). Pada beberapa penelitian, dikatakan diabetes tipe 2 didapatkan lebih banyak pada laki-laki dibandingkan perempuan karena lemak visceral lebih besar pada laki-laki, ${ }^{12}$ pada penelitian ini kemungkinan jumlah sampel yang tidak memenuhi, menyebabkan hingga tidak menggambarkan prevalensinya. Kelompok umur terbanyak pada pasien ini adalah pada kelompok umur 51-60 tahun $(47,6 \%)$, diikuti kelompok umur 61-70 tahun $(37,8 \%), 41-50$ tahun $(12,2 \%)$ dan $31-40$ tahun $(2,4 \%)$, demikian halnya dengan penelitian di China, menemukan bahwa diabetes melitus tipe 2, prevalensinya tujuh kali lebih tinggi pada umur 55-74 tahun daripada umur 20-34 tahun. ${ }^{13}$

Tabel 1. Distribusi sampel berdasarkan demografi

\begin{tabular}{lcc}
\hline $\begin{array}{l}\text { Populasi pasien } \\
\text { diabetes melitus } \\
\text { tipe 2 }\end{array}$ & $\mathrm{n}$ & $\%$ \\
\hline $\begin{array}{l}\text { Jenis kelamin } \\
\text { Laki-laki }\end{array}$ & 34 & 41,5 \\
$\quad \begin{array}{l}\text { Perempuan } \\
\text { Usia (tahun) }\end{array}$ & 48 & 58,5 \\
$31-40$ & & \\
$41-50$ & 2 & 2,4 \\
$51-60$ & 10 & 12,2 \\
$61-70$ & 39 & 47,6 \\
& 31 & 37,8
\end{tabular}

\begin{tabular}{lcc} 
Tekanan darah & & \\
Normal & 14 & 17,1 \\
Prehipertensi & 18 & 22,0 \\
Hipertensi gr.1 & 29 & 35,4 \\
Hipertensi gr.2 & 21 & 25,6 \\
Indeks massa tubuh & & \\
Underweight & 3 & 3,7 \\
Normal & 35 & 42,7 \\
Overweight & 33 & 40,2 \\
Obesitas-1 & 8 & 9,8 \\
Obesitas-2 & 3 & 3,7 \\
Jumlah & 82 & 100,0 \\
\hline
\end{tabular}

Tabel 2. Distribusi sampel proteinuria dan eGFR

\begin{tabular}{lcc}
\hline $\begin{array}{l}\text { Populasi pasien } \\
\text { diabetes melitus } \\
\text { tipe 2 }\end{array}$ & $\mathrm{n}$ & $\%$ \\
\hline $\begin{array}{l}\text { Proteinuria } \\
0\end{array}$ & 41 & 50,0 \\
1 & 12 & 14,6 \\
2 & 14 & 11,0 \\
3 & 11 & 13,4 \\
4 & 4 & 4,9 \\
eGFR & & \\
Stadium 1 & 11 & 13,4 \\
Stadium 2 & 32 & 39,0 \\
Stadium 3A & 17 & 20,7 \\
Stadium 3B & 13 & 15,9 \\
Stadium 4 & 3 & 3,7 \\
Stadium 5 & 6 & 7,3 \\
Jumlah & 82 & 100,0 \\
\hline
\end{tabular}

Pada Tabel 1 juga memperlihatkan hipertensi grade 1 sebanyak 29 orang $(35,4 \%)$, demikian halnya ditemukan pada penelitian Hayashi et al bahwa adanya peningkatan tekanan darah memiliki faktor risiko yang tinggi untuk terjadinya diabetes melitus tipe 2 dibandingkan tekanan darah normal. ${ }^{14}$ Index massa tubuh pasien diabetes melitus tipe 2 terbanyak adalah overweight sebanyak 33 orang (40,2\%). Hal ini sesuai dengan penelitian Gray et al bahwa peningkatan indeks massa tubuh 
akan diikuti dengan peningkatan risiko terjadinya diabetes melitus tipe $2 .^{15}$

Berdasarkan Tabel 2 Pasien diabetes melitus tipe 2 terbanyak pada proteinuria positif yaitu +2 sebanyak 14 orang $(11,0 \%)$.
Kemudian pada stadium PGK yang terbanyak adalah stadium $2(39,0 \%)$ diikuti oleh stadium 3A $(20,7 \%)$, stadium 3B $(15,9 \%)$, stadium $1(13,4 \%)$, stadium 5 $(7,3 \%)$ dan stadium $4(3,7 \%)$.

Tabel 3. Hubungan resistive index ginjal kanan terhadap eGFR

\begin{tabular}{lccccccc}
\hline eGFR & \multicolumn{9}{c}{ Resistive Index ginjal kanan } \\
& Min & Maks & Rata-rata & Median & SD & p & $r$ \\
\hline Stadium 1 & 0,60 & 0,70 & 0,64 & 0,65 & 0,03 & $<0,0001$ & 0,604 \\
Stadium 2 & 0,61 & 0,81 & 0,64 & 0,68 & 0,04 & & \\
Stadium 3A & 0,66 & 0,75 & 0,69 & 0,69 & 0,02 & & \\
Stadium 3B & 0,64 & 0,77 & 0,71 & 0,71 & 0,03 & & \\
Stadium 4 & 0,77 & 0,80 & 0,78 & 0,79 & 0,01 & & \\
Stadium 5 & 0,70 & 0,84 & 0,79 & 0,81 & 0,04 & & \\
\hline
\end{tabular}

Tabel 4. Hubungan resistive index ginjal kiri terhadap eGFR

\begin{tabular}{lccccccc}
\hline eGFR & \multicolumn{7}{c}{ Resistive Index ginjal kiri } \\
& Min & Maks & Rata-rata & Median & SD & $\mathrm{p}$ & $\mathrm{r}$ \\
\hline Stadium 1 & 0,62 & 0,74 & 0,65 & 0,64 & 0,04 & $<0,0001$ & 0,666 \\
Stadium 2 & 0,62 & 0,78 & 0,69 & 0,69 & 0,03 & & \\
Stadium 3A & 0,66 & 0,79 & 0,71 & 0,71 & 0,04 & & \\
Stadium 3B & 0,65 & 0,80 & 0,73 & 0,72 & 0,04 & & \\
Stadium 4 & 0,78 & 0,81 & 0,80 & 0,81 & 0,01 & & \\
Stadium 5 & 0,73 & 0,82 & 0,80 & 0,81 & 0,03 & & \\
\hline
\end{tabular}

Berdasarkan Tabel 3 didapatkan nilai mean resistive index ginjal kanan meningkat sesuai dengan peningkatan stadium PGK (penurunan eGFR), pada stadium 1 didapatkan RI 0,64; stadium 2 RI 0,64; stadium $3 A$ 0,69; stadium $3 B$ RI 0,71 ; stadium 4 RI 0,78; dan stadium 5 RI 0,79. Dan pada Tabel 4 didapatkan nilai mean resistive index ginjal kiri meningkat sesuai dengan peningkatan stadium PGK (penurunan eGFR), stadium 1 didapatkan nilai mean RI 0,65, stadium 2 RI 0,69, stadium $3 A$ A 0,71 , stadium $3 B$ RI 0,73 , stadium 4 RI 0,80, stadium 5 RI 0,80. Pada Tabel 3 dan 4 dapat juga dilihat bahwa antara stadium PGK dengan resistive index ginjal kanan dan kiri terdapat hubungan yang signifikan serta memiliki korelasi yang cukup tinggi ( $r=0,666$ dan $r=0,604$ ). Dari hasil penelitian ini didapatkan peningkatan stadium PGK (penurunan eGFR) diikuti dengan peningkatan resistive index kedua ginjal serta hubungan yang signifikan $(r=0,666 ; \quad p=<0,0001)$ dan $(r=0,604$; $p=<0,0001)$ didapatkan korelasi yang cukup tinggi antara resistive index ginjal kanan dan ginjal kiri dengan eGFR, bahwa semakin tinggi nilai resistive index pada ginjal kanan dan ginjal kiri, maka semakin rendah eGFR. Hal ini Sesuai dengan penelitian Fallah et al dimana ditemukan nilai koefisien korelasi yang bermakna $(r=0,283$ dan $p=0,01),{ }^{16}$ begitu pun pada penelitian Mancini et al didapatkan 
korelasi yang sedang $(r=0,398 ; p=<0,001)$. Gulek et al menuliskan bahwa dengan adanya peningkatan RI dari arteri interlobar harus dipikirkan bahwa telah terdapat kerusakan ginjal stadium lanjut. ${ }^{17}$ Penelitian Bige et al menyebutkan bahwa $\mathrm{RI}>0,7$ berhubungan dengan berat dan luasnya perubahan jaringan seperti fibrosis interstitial, arteriosclerosis berat dan penurunan fungsi ginjal. ${ }^{18} \mathrm{RI}$ akan meningkat seiring dengan peningkatan stadium (penurunan eGFR) dan menunjukkan korelasi dengan gangguan fungsi ginjal dan kerusakan anatomi dan histologi. Terjadinya peningkatan RI berhubungan dengan berat dan luasnya perubahan jaringan seperti tubulointerstitial fibrosis dan arteriosclerosis, semakin luas kerusakan jaringan maka RI akan semakin meningkat. ${ }^{15}$

Tabel 5. Hubungan resistive index ginjal kanan pada pasien diabetes melitus tipe 2

\begin{tabular}{ccccccc}
\hline Proteinuria & \multicolumn{7}{c}{ Resistive Index ginjal kanan } \\
& Min & Maks & Rata-rata & Median & SD & $\mathrm{p}$ \\
\hline 0 & 0,60 & 0,80 & 0,67 & 0,68 & 0,04 & $<0,0001$ \\
+1 & 0,64 & 0,82 & 0,69 & 0,69 & 0,04 & \\
+2 & 0,68 & 0,84 & 0,72 & 0,70 & 0,04 & \\
+3 & 0,66 & 0,77 & 0,71 & 0,71 & 0,03 & \\
+4 & 0,73 & 0,82 & 0,79 & 0,80 & 0,04 & \\
\hline
\end{tabular}

Tabel 6. Hubungan resistive index ginjal kiri pada pasien diabetes melitus tipe 2

\begin{tabular}{ccccccc}
\hline Proteinuria & \multicolumn{7}{c}{ Resistive Index ginjal kiri } \\
& Min & Maks & Rata-rata & Median & SD & p \\
\hline 0 & 0,62 & 0,81 & 0,68 & 0,68 & 0,04 & $<0,0001$ \\
+1 & 0,65 & 0,81 & 0,70 & 0,71 & 0,04 & \\
+2 & 0,66 & 0,82 & 0,72 & 0,72 & 0,04 & \\
+3 & 0,68 & 0,80 & 0,75 & 0,78 & 0,04 & \\
+4 & 0,71 & 0,82 & 0,79 & 0,81 & 0,05 & \\
\hline
\end{tabular}

Berdasarkan Tabel 5 didapatkan nilai mean resistive index ginjal kanan meningkat diikuti dengan peningkatan kadar proteinuria, pada protein negatif didapatkan $\mathrm{RI}$ 0,67, namun di dapatkan nilai maksimum pada proteinuria negative dengan $\mathrm{RI}=0,80$, kemudian diikuti dengan proteinuria positif +1 RI 0,69; +2 RI 0,72; + 3 RI 0,71; +4 RI 0,79. Pada tabel di atas juga didapatkan hubungan yang signifikan ( $p<0.0001$ ) dan pada Tabel 6 didapatkan nilai mean resistive index ginjal kiri meningkat diikuti dengan peningkatan kadar proteinuria, pada protein negatif didapatkan RI 0,68, namun nilai maksimum didapatkan mengalami peningkatan $\mathrm{RI}$ 0,81, kemudian nilai mean meningkat diikuti dengan proteinuria positif +1 RI 0,70; +2 RI 0,70; + 3 RI 0,72; $+4 \mathrm{RI} 0,79$. Pada tabel di atas juga didapatkan hubungan yang signifikan $(p<0,0001)$. Hal ini sesuai dengan penelitian Platt et al, yang menunjukkan bahwa pada pasien diabetes melitus tipe 2 , pembuluh darah arteri mengalami perubahan akibat kerusakan mikro 
vaskular. ${ }^{6}$ Pada penelitian selanjutnya Fallah et al, melakukan penelitian terhadap pasien diabetes melitus tipe 2 , dimana ditemukan nilai koefisien korelasi yang bermakna $(r=0,283$ dan $p=0,01)$, Pasien dengan makroalbuminuria menunjukkan RI yang jauh lebih tinggi, dimana RI berkorelasi dengan proteinuria bahwa dengan hasil tersebut mencerminkan adanya kerusakan struktural pada membran glomerulus yang mengakibatkan hilangnya permeabilitas selektif. ${ }^{16}$ Kemudian selanjutnya pada penelitian Genov et al ditemukan korelasi resistive index ginjal dengan proteinuria. ${ }^{4}$ Begitu pun pada penelitian Mancini et al didapatkan korelasi yang sedang $(r=0,398, p=<0,001) .{ }^{5}$ Adanya peningkatan resistive index ginjal pada pasien tanpa proteinuria dicurigai terjadi peningkatan
eGFR dimana hal ini sesuai dengan penelitian dan pada penelitian Iseki et al di dapatkan juga hubungan yang kuat antara eGFR (stadium akhir PGK) dengan proteinuria. ${ }^{20}$ Arteri intrarenalis di sekitar korteks ginjal yang dikelilingi oleh lemak perirenal, mencerminkan awal perubahan dari perfusi dan hemodinamika ginjal. ${ }^{3}$ Sehingga Resistive index dapat dikatakan sebagai prediktor independen dari penurunan fungsi ginjal. Pada tabel 5 juga didapatkan ada sebagian kecil data terlihat mengalami peningkatan resistive index pada non proteinuria, namun ditelusuri pasien tersebut mengalami peningkatan stadium PGK (penurunan eGFR), dimana diketahui pengaruh penurunan eGFR dapat berkorelasi positif dengan peningkatan resistive index ginjal.

Tabel 7. Hubungan antara proteinuria, eGFR, dan resistive index ginjal kanan dan kiri

\begin{tabular}{lccc}
\hline \multicolumn{1}{c}{ Nilai } & \multicolumn{2}{c}{ Proteinuria } & $\mathrm{n}$ \\
\hline eGFR & $\mathrm{r}$ & $\mathrm{p}$ & 82 \\
Resistive index kanan & 0,449 & $<0,0001$ & 82 \\
Resistive index kiri & 0,449 & $<0,0001$ & 82 \\
\hline
\end{tabular}

Berdasarkan Tabel 7 menunjukkan bahwa antara proteinuria dan eGFR terdapat hubungan yang signifikan $(p<0,0001)$ dengan korelasi yang cukup $(r=0,44)$, adapun antara proteinuria dan resistive index ginjal kanan dan kiri terdapat hubungan yang signifikan $(p<0,0001)$ dengan korelasi yang kuat $(r=0,449$ dan $r=0,551)$. Hal ini sesuai dengan penelitian Imai et al menemukan bahwa eGFR dua kali lipat akan menurun pada pasien proteinuria dibandingkan pada pasien tanpa disertai proteinuria dengan eGFR menggunakan persamaan MDRD (Modification of Diet in Renal Disease) ${ }^{21}$, dan pada penelitian Iseki et al di dapatkan juga hubungan yang kuat antara eGFR (stadium akhir PGK) dengan proteinuria. ${ }^{20}$

\section{SIMPULAN}

Dari penelitian ini didapatkan hubungan yang signifikan antara resistive index ginjal kanan dan kiri dengan korelasi yang kuat. Semakin tinggi kadar proteinuria, maka semakin tinggi nilai resistive index ginjal pada pasien diabetes melitus tipe 2 . 
Terdapat hubungan yang cukup kuat antara nilai resistive index ginjal kanan dan kiri dengan eGFR MDRD pada pasien diabetes melitus tipe 2, dimana semakin tinggi nilai resistive index ginjal (RI), maka semakin rendah nilai eGFR (semakin tinggi stadium PGK). Sehingga dapat disimpulkan
Nilai resistive index dari arteri renalis dapat memberikan indikasi perubahan pembuluh darah yang paling diandalkan dan merupakan parameter yang dapat digunakan dalam memonitor penyakit ginjal.

\section{DAFTAR PUSTAKA}

1. World Health Organization. Global report on diabetes: executive summary. Geneva: World Health Organization; 2016. Available at [Link].

2. Aldukhayel, A. Prevalence of diabetic nephropathy among Type 2 diabetic patients in some of the Arab countries. Int J Health Sci (Qassim). 2017; 11(1):1-4. [PubMed] [PMC free article].

3. Fiorini F, Barozzi L. The role of ultrasonography in the study of medical nephropathy. J Ultrasound. 2007; 10(4):161-167. doi: 10.1016/j.jus.2007.09.001. [PMC free article].

4. Genov D, Kundurdgiev A, Pencheva V. Resistive Index for the Evaluation of Renal Damage in Diabetes Mellitus Type 2. Open Journal of Internal Medicine. 2018; 8(2):160-166. doi: 10.4236/ojim.2018.82016.

5. Mancini M, Masulli M, Liuzzi R, Mainenti PP, Ragucci M, Maurea S, et al. Renal duplex sonographic evaluation of type 2 diabetic patients. J Ultrasound Med. 2013; 32(6):1033-40. doi: 10.7863/ultra.32.6.1033. [PubMed].

6. Masulli M, Mancini M, Liuzzi R, Daniele S, Mainenti PP, Vergara E. Measurement of the intrarenal arterial resistance index for the identification and prediction of diabetic nephropathy. Nutr Metab Cardiovasc Dis. 2009; 19(5):358-64. doi: 10.1016/j.numecd.2008.07.003. [PubMed].

7. Viazzi F, Leoncini G, Derchi LE, Pontremoli R. Ultrasound Doppler renal resistive index: a useful tool for the management of the hypertensive patient. J Hypertens. 2014; 32(1):149-53. doi: 10.1097/HJH.0b013e328365b29c. [PubMed] [PMC free article].

8. Hanamura K, Tojo A, Kinugasa S, Asaba K, Fujita T. The resistive index is a marker of renal function, pathology, prognosis, and responsiveness to steroid therapy in chronic kidney disease patients. Int J Nephrol. 2012; 2012:139565. doi: 10.1155/2012/139565. [PubMed] [PMC free article].

9. Tublin ME, Bude RO, Platt JF. The Resistance index in Renal Doppler sonography: Where Do We Stand?. Am J Roentgenol. 2003; 180:885-892. doi: 10.2214/ajr.180.4.1800885.

10. American Diabetes Association. Standards of Medical Care for Patients With Diabetes Mellitus. Diabetes Care. 2002; 25(suppl 1):s33-s49. doi: 10.2337/diacare.25.2007.S33.

11. UKidney Internet School of Nephrology. EGFR calculator. [Internet]. BrightBean Solutions Inc; 2018. Available at [Link].

12. Nordström A, Hadrévi J, Olsson T, Franks PW, Nordström P. Higher Prevalence of Type 2 Diabetes in Men Than in Women Is Associated With Differences in Visceral Fat Mass. J Clin Endocrinol Metab. 2016; 101(10):3740-3746. doi: 10.1210/jc.2016-1915. [PubMed]. 
13. Yang $L$, Shao J, Bian $Y, W u ~ H$, Shi L, Zeng L, et al. Prevalence of type 2 diabetes mellitus among inland residents in China (2000-2014): A meta-analysis. J Diabetes Investig. 2016; 7(6):845-852. doi: 10.1111/jdi.12514. [PubMed] [PMC free article].

14. Hayashi T, Tsumura K, Suematsu C, Endo G, Fujii S, Okada K. High normal blood pressure, hypertension, and the risk of type 2 diabetes in Japanese men: The Osaka Health Survey. Diabetes Care. 1999; 22(10):1683-7. doi: 10.2337/diacare.22.10.1683. [PubMed].

15. Gray N, Picone G, Sloan F, Yashkin A. The Relationship between BMI and Onset of Diabetes Mellitus and its Complications. South Med J. 2015; 108(1):29-36. doi: 10.14423/SMJ.0000000000000214. [PMC free article].

16. Fallah M, Nafisi-Moghadam R, Nouri N. Relationship between Intra-renal Arterial Resistance Index (RI) and Albuminuria in Diabetic Patients. Irian Journal of Diabetes and Obesity. 2012; 4(1):7-10. [Abstract/FREE full-text].

17. Gulek B, Soker G, Erken E, Adam FU, Varan HI, Ada S, et al. The Usefulness of Renal Doppler Parameters in Chronic Kidney Disease: Is There a Cut-Off Value to Estimate End Stage Kidney Disease? Open Journal of Radiology. 2016; 6(1):18-23. doi: 10.4236/ojrad.2016.61003.

18. Bigé $N$, Lévy PP, Callard P, Faintuch JM, Chigot V, Jousselin V, et al. Renal arterial resistive index is associated with severe histological changes and poor renal outcome during chronic kidney disease. BMC Nephrol. 2012; 13:139. doi: 10.1186/1471-2369-13-139. [PubMed] [PMC free article].

19. Milovanceva-Popovska M, Dzikova S. Progression of diabetic nephropathy: value of intrarenal resistive index (RI). Prilozi. 2007; 28(1):69-79. [PubMed].

20. Iseki K, Ikemiya $Y$, Iseki $C$, Takishita S. Proteinuria and the risk of developing end-stage renal disease. Kidney Int. 2003; 63(4):1468-74. doi: 10.1046/j.1523-1755.2003.00868.x. [PubMed].

21. Imai E, Horio M, Yamagata K, Iseki K, Hara S, Ura N, et al. Slower decline of glomerular filtration rate in the Japanese general population: a longitudinal 10-year follow-up study. Hypertens Res. 2008; 31(3):433-41. doi: 10.1291/hypres.31.433. [PubMed]. 